\title{
Eltérő típusú tartástechnológiák hatása a szürke harcsa (Silurus glanis) termelési paramétereire, valamint a víz és az üledék minőségére
}

\author{
NAGY Zoltán ${ }^{1,2 *}$, GÁL Dénes (iD) 3, HANCZ Csaba (iD) 1, BIRÓ Janka² \\ ${ }^{1}$ Kaposvári Egyetem, Agrár- és Környezettudományi Kar, 7400 Kaposvár, Guba S. u. 40. \\ 2 NAIK Halászati Kutatóintézet, 5540 Szarvas, Anna-liget u. 35. \\ ${ }^{3}$ GEOFISH Kft., 6600 Szentes, Árpád u. 44.
}

\begin{abstract}
Effects of different rearing technologies on production traits, water and sediment quality in European catfish (Silurus glanis) farming

Author: Zoltán Nagy ${ }^{1,2}$, Dénes Gál ${ }^{3}$, Csaba Hancz ${ }^{1}$, Janka Biró ${ }^{2}$

Affiliation: ${ }^{1}$ Kaposvár University, Faculty of Agricultural and Environmental Sciences, 7400 Kaposvár, Guba s. u. 40, Hungary; ${ }^{2}$ NARIC Research Institute for Fisheries and Aquaculture, 5540 Szarvas, Annaliget u. 35, Hungary; ${ }^{3}$ GEOFISH Kft., 6600 Szentes, Árpád u. 44.

Aim of the study was to investigate the effect of two different rearing technologies (monoculture (M), intensive-extensive pond system (I-E)) on the production traits, water and sediment quality in case of European catfish. During a 153 days long trial two years old European catfish (mean individual weight of $485.7 \pm 3.4 \mathrm{~g}$ ) and common carp (mean individual weight of $348.9 \pm 2.5 \mathrm{~g}$ ) were stocked into the experimental system. Final mean weight of the fish were as follows: $1932.9 \pm 194.5 \mathrm{~g}$ (European catfish) and $2266.9 \pm 87.56 \mathrm{~g}$ (common carp). No significant differences were observed in the production traits. Specific growth rate (SGR) was lower $(0.9 \pm 0.1 \%$ /day) than expected. Significant differences were found in nitrate-N, nitrite-N, orthophosphate and total suspended solids content. Significant decrease was observed in the Kjeldahl-N and phosphate content of sediment in the extensive-intensive combined system. These results suggest that transformation of the nutrients in the combined system exceeds that of monoculture; significant amount of organic $\mathrm{N}$ and $\mathrm{P}$ compounds were removed and accumulated in the additional common carp yield.
\end{abstract}

Keywords: European catfish, combined system, water quality

\section{BEVEZETÉS}

A tengerek halállományának nagymértékű lehalászása következtében az 1980-as évek közepétől a természetes vízi fogások mennyisége stagnál, évi 8090 millió tonna között változik. A világ akvakultúra termelésében előállított halak mennyisége az 1950-es évektől folyamatosan emelkedik. 2016-ban a világ haltermelése elérte a 171 millió tonnát, melynek $47 \%$-át az akvakultúra szektor állította elő $(F A O, 2018)$.

Mivel a fehérje iránti globális kereslet folyamatosan növekszik, az igények kielégítése érdekében az akvakultúrás termelés is tovább fejlődik, elsősorban 
intenzív tavi termelés formájában (Zhang és mtsai., 2020). Bár ezekben az intenzív tavakban hatékonyan lehet élelmiszert elóállítani, ez súlyos környezeti problémákat okozhat. A halak általában a bevitt tápanyagoknak csak egy részét hasznosítják, míg a hasznosítatlan tápanyagok visszamaradnak a tavak vízterében, illetve az üledékben (Sun és Boyd, 2013).

A haltermelés transzformációs hatékonysága, valamint a környezetre gyakorolt hatása a különböző intenzitású rendszerek összekapcsolásával mérsékelhető. Az 1980-as évek végén, 1990-es évek elején Izraelben hoztak létre ilyen haltermelő rendszereket (Avnimelech és mtsai., 1986). A nagy népesítésű tavak hozzájárulnak a halbiomassza növekedéséhez ellenőrzött körülmények között, maximálisan kihasználva a rendelkezésre álló vízteret. A nagy népesítésű tavak egyik legnagyobb problémáját a mérgező szervetlen nitrogénformák, a szabad ammónia és a nitrit felhalmozódása jelenti (Colt és Armstrong, 1979; Palachek és Tomaso, 1984). Ennek a problémának az egyik megoldási lehetősége a nagy mennyiségű friss vízzel történő "átöblítés", azonban ez nagyban függ attól, hogy mennyi friss víz áll rendelkezésre. Másik lehetőség a víz biofiltereken történő átáramoltatása. A megfelelő működéshez szükséges biofilterek bekerülési és működtetési költségei igen magasak. Szintén megoldás lehet az intenzív-extenzív kombinált rendszer alkalmazása (Diab és mtsai., 1992).

A szürke harcsa (Silurus glanis) Európa legnagyobbra növő ragadozó hala. Hazánkban őshonos halfaj. A takarmányértékesítő képessége rendkívül jó, a növekedése gyors. Könnyen tápra szoktatható, jó a technológia tűrése. Ezen tulajdonságok miatt az intenzív termelési igényeknek és körülményeknek teljes mértékben megfelel, állategészségügyi kontroll mellett. Hazai tenyésztése nagyon sok lehetőséget rejt még magában, mind technológiai, mind genetikai szempontból.

A kísérlet célja annak a megállapítása volt, hogy két eltérő tartástechnológia (monokultúra (M), intenzív-extenzív tavi rendszer (I-E)) milyen hatással van a szürke harcsa termelési paramétereire, valamint a tavak vízminőségére és az üledék kémiai összetételére.

\section{ANYAG ÉS MÓDSZER}

\section{Kísérleti rendszer}

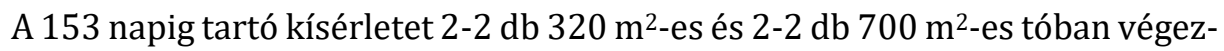
tük. A kísérleti állományok kihelyezése monokultúrában (M), illetve intenzívextenzív (I-E) elrendezésben történt. Az I-E kezelés esetében a szürke harcsákat $2 \mathrm{db} 3 \times 3 \times 2 \mathrm{~m}$-es (320 $\mathrm{m}^{2}$-es tó), valamint 2 db 3×6x2m-es ketrecekben 
(700 m²-es tó) helyeztük el. A ketreceken kívüli víztérbe kétnyaras pontyokat helyeztünk ki. A monokultúrás kezelésnél a tavakba szürke harcsát telepítettünk. A kísérletnél tófenékre kihelyezett ketreceket használtunk. A tavak levegőztetése folyamatos üzemben, egyedileg, lapátkerekes levegőztetővel (MASTER 750, FIAP Gmbh, Németország) történt. Az állományok etetését központilag vezérelt automata önetetők (FIAP Gmbh, Németország) végezték. Az etetés reggel 9 és délután 16 óra között történt. A takarmányt az önetetők óránként juttatták ki a halak számára. A naponta kijuttatott takarmány mennyisége a harcsaállomány tömegének a 2,5 \%-a volt. A tavakon folyamatos vízcserét nem biztosítottunk, a párolgó víz pótlása a Körös folyóból történt.

\section{Kísérleti állomány}

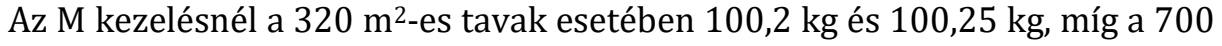
m²-es tavaknál 200,9 kg és 199,6 kg hal került kihelyezésre. Az I-E kezelésnél $100,1 \mathrm{~kg}$ és $100,35 \mathrm{~kg}$ halat helyeztünk a $320 \mathrm{~m}^{2}$-es tavakba telepített ketrecekbe. A $700 \mathrm{~m}^{2}$-es tavakba elhelyezett ketrecekbe 200,2 kg és 200,2 kg halat helyeztünk. Az I-E kezelésnél a ketrecen kívüli víztérbe 25 kg (320 m²-es tó) valamint $50 \mathrm{~kg}$ (700 $\mathrm{m}^{2}$-es tó) kétnyaras pontyot telepítettünk a harcsák által el nem fogyasztott táp, valamint a harcsa ürülékét hasznosító élőlények fogyasztása céljából. A kísérlet kezdetekor a kihelyezett szürke harcsa állomány átlagos testtömege $485,7 \pm 3,4 \mathrm{~g}$ volt $(\mathrm{n}=2480)$. A pontyok átlagos testtömege $348,9 \pm 2,5$ g volt $(n=432)$.

\section{Kísérleti takarmány}

A vizsgálat során a kihelyezett állomány a kísérlet teljes ideje alatt kereskedelmi forgalomban kapható, 6 mm-es szemnagyságú, süllyedő Aller Bronze haltápot kapott. A naponta kijuttatott takarmányadag a próbahalászatot követően módosításra került. A vizsgálat során alkalmazott takarmány kémiai öszszetételét az 1. táblázat mutatja.

\section{Kémiai analízis}

A víz hőmérsékletét, oldott oxigénszintjét, vezetőképességet és a pH-t (WTW Multi 3430, WTW GmbH., Németország) hétköznap reggel 8 órakor, napi rendszerességgel mértük. A kísérlet indulásakor, majd ezt követően minden második héten, valamint a vizsgálat befejezésekor minden tóból víz- és üledékmintát vettünk. A vízmintákat vizsgálva megmértük az ammónium- $\mathrm{N}\left(\mathrm{NH}_{4}-\mathrm{N}\right)$, nitrit- $\mathrm{N}\left(\mathrm{NO}_{2}-\mathrm{N}\right)$, nitrát- $\mathrm{N}\left(\mathrm{NO}_{3}-\mathrm{N}\right)$, ortofoszfát-P $\left(\mathrm{PO}_{4}-\mathrm{P}\right)$ (Quickhem 8500 , Hach, Loveland, USA), összes P (TP), összes N (TN) (Lange Gaminede P, N), klorofill- 
a (Chl-a) (DR/4000U, Hach, Loveland, USA) összes lebegőanyag (TSS) (ICAP 6000, ICP-OES, Thermo Fisher Scientific Inc.) paramétereket. Az üledékmintákból meghatároztuk a Kjeldahl-N (KN) (Büchi B-324) és a foszfor (P) (CAP 6000, ICP-OES, Thermo Fisher Scientific Inc.) mennyiségét.

\section{1. táblázat}

A kísérlet során használt, kereskedelmi forgalomban kapható táp kémiai összetétele

\begin{tabular}{|c|c|c|c|c|c|c|c|}
\hline & $\begin{array}{l}\text { nyers } \\
\text { fehérje }^{1} \\
(\%)\end{array}$ & $\begin{array}{l}\text { nyers } \\
\text { zsír² } \\
(\%)\end{array}$ & $\begin{array}{l}\text { nyers } \\
\text { hamu } \\
(\%)\end{array}$ & $\begin{array}{l}\text { nyers } \\
\text { rost }^{4} \\
(\%)\end{array}$ & $\begin{array}{l}P^{5} \\
(\%)\end{array}$ & $\begin{array}{l}M^{6} \\
(M J)\end{array}$ & $\begin{array}{l}\mathrm{DE}^{7} \\
(\mathrm{MJ})\end{array}$ \\
\hline Aller Bronze* & 45 & 15 & 6,5 & 3,2 & 1,1 & 21,2 & 17,6 \\
\hline
\end{tabular}

https://www.aller-aqua.com/species/warm-freshwater-species/european-catfish. * A táp összetevői: toll-liszt, halliszt, hemoglobin, baromfiliszt, baromfiolaj, repce, repceolaj, szója, napraforgó fehérje konc., tritikálé, vitaminok, ásványi anyagok, búza

Table 1. Chemical composition of the experimental diet. ${ }^{1}$ Crude protein, ${ }^{2}$ Crude fat, ${ }^{3}$ Ash,${ }^{4}$ Crude fibre, ${ }^{5}$ Phosphorus, ${ }^{6}$ Metabolisable energy, ${ }^{7}$ Digestible energy

\section{Mérések, termelési paraméterek számítása}

A kísérlet kezdetekor és befejezésekor a halak testtömegét csoportosan (20 db) mértük digitális mérleg segítségével, 5,0 g pontossággal. A vizsgálat kezdetét követő minden második héten a kihelyezett állomány legalább 20 \%-át csoportosan mértük meg.

A halak tömeggyarapodása (g) mellett a relatív növekedést (\%), a növekedési sebességet (SGR) és a takarmányértékesítést (FCR) is kiszámoltuk az alábbi képletek alkalmazásával:

tömeggyarapodás $=\mathrm{W}_{\mathrm{t}}-\mathrm{W}_{\mathrm{i}}(\mathrm{g})$, ahol $\mathrm{W}_{\mathrm{t}}$ a befejező, $\mathrm{W}_{\mathrm{i}}$ az induló testtömeget $(\mathrm{g})$ jelöli

relatív növekedés $=\left[\left(\mathrm{W}_{\mathrm{t}}-\mathrm{W}_{\mathrm{i}}\right) / \mathrm{W}_{\mathrm{i}}\right] \times 100(\%)$, ahol $\mathrm{W}_{\mathrm{t}}$ a befejező, $\mathrm{W}_{\mathrm{i}}$ az induló testtömeget $(\mathrm{g})$ jelöli

$S G R=\left(\ln \mathrm{W}_{\mathrm{t}}-\ln \mathrm{W}_{\mathrm{i}}\right) / \mathrm{t} \times 100(\% / \mathrm{nap})$, ahol $\mathrm{W}_{\mathrm{t}}$ a befejező, $\mathrm{W}_{\mathrm{i}}$ az induló testtömeget (g), $\mathrm{t}$ az eltelt időt (nap) jelöli

$F C R=\mathrm{F} /\left(\mathrm{W}_{\mathrm{t}}-\mathrm{W}_{\mathrm{i}}\right)(\mathrm{g} / \mathrm{g})$, ahol $\mathrm{F}$ az elfogyasztott takarmány mennyisége grammban kifejezve, $\mathrm{W}_{\mathrm{t}}$ a befejező, míg $\mathrm{W}_{\mathrm{i}}$ az induló átlagtömeg (g). 


\section{Statisztikai módszerek}

A statisztikai értékelést az IBM SPSS Statistics V22.0 (2013) programcsomaggal végeztük. A kísérlet befejezését követően az adatok normális eloszlásának a vizsgálatához Shapiro-Wilk tesztet és Kolmogorov-Szmirnov próbát, míg a varianciák homogenitásának vizsgálatához Levene tesztet használtunk. Az egytényezős varianciaanalízist követően a kezelésátlagokat LSD post hoc teszttel hasonlítottuk össze. Ahol az eloszlás nem volt normális, az átlagok öszszehasonlításához nem paraméteres Kruskal-Wallis tesztet használtunk. Az alkalmazott szignifikancia szint $\mathrm{p}<0,05$ volt.

\section{EREDMÉNYEK ÉS ÉRTÉKELÉS}

A kísérleti állomány növekedési paraméterei a 2. táblázatban láthatóak. A vizsgálat ideje alatt mind a szürke harcsa (M: $9 \mathrm{db}$; I-E: $29 \mathrm{db}$ ), mind pedig a ponty (14 db) állományban észleltünk elhullást. A kísérlet befejezésekor, a csoportok átlagos testtömege 1932,9ะ194,5 g volt. Az I-E kezelésnél a ketreceken kívüli víztérbe kihelyezett pontyok átlagos testtömege a kísérlet végén $2266,9 \pm 87,56$ g volt. A két csoport adatait együttesen vizsgálva, az induló és befejező testtömegek között szignifikáns különbséget nem találtunk. A kezelések záró mérését követően azt az eredményt kaptuk, hogy az I-E kezelésnél a harcsák átlagos testtömege 100 grammal nagyobb volt az M kezelés állományához képest. Mind a két csoportnál a kihelyezett állomány a kísérlet végére a kihelyezéskori testtömegét megnégyszerezte (M: 3,92x; I-E: 4,13x). A további növekedési paraméterek vizsgálatánál a csoportok között szintén nem találtam szignifikáns különbséget. Ragadozó halak esetében a közel 2 \%/nap, vagy ezt meghaladó növekedés a kívánatos. Vizsgálatunkban az SGR adatok nagyon alacsony értékeket $(0,9 \pm 0,1 \% /$ nap) mutattak mind a két kezelésnél. Az I-E kezelésnél a ketreceken kívüli víztérbe kihelyezett pontyok külön takarmányt nem kaptak. Ennek következtében az SGR és FCR értékeket nem tudtam kiszámolni. A táblázat adataiból jól látszik, hogy annak ellenére, hogy kiegészítő takarmányt nem kaptak, a kihelyezéskori átlagos testtömegüket a kísérlet végére majdnem meghétszerezték (6,8x).

Kibria és Haque (2018) ponttyal és zsákos harcsával (Heteropneustes fos-

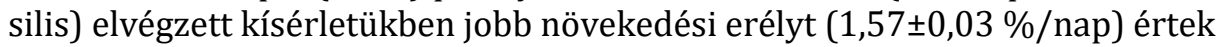
el. Vizsgálatomban a takarmányértékesítés kiszámítását követően kapott eredmények szintén elmaradtak a gyakorlatban kívánatosnak tartott értékekhez (1 g/g-hoz közelítő érték) képest. Ludwig (1996) csatornaharcsával (Ictalurus punctatus) és tűzcsellével (Pimephales promelas) végzett kísérletében hasonló eredményt kapott a végső testtömeg tekintetében. Yi és mtsai. (2003) 
hibrid harcsával (Clarias macrocephalus x C. gariepinus) és nílusi tilápiával (Oreochromis niloticus) végzett kísérletükben a monokultúrás rendszerben jobb FCR értékeket tapasztaltak. Yi és Lin (2001) Délkelet-Ázsiában, nílusi tilápiával végzett kísérletükben a tavakban növelték az ott elhelyezett ketrecek számát. Azt tapasztalták, hogy a ketrecek számának növekedésével a ketrecekben lévő állomány átlagos testtömege szignifikánsan csökkent, míg a tavakban elhelyezett állományoké szignifikánsan növekedett. Osztott tavi rendszerben, csatornaharcsával végzett vizsgálatukban Jescovitch és mtsai. (2017) a kontroll és a kezelt csoportok FCR értékei között nem találtak szignifikáns különbséget. Yi és mtsai. (1996) nílusi tilápiával végzett vizsgálatukban azt tapasztalták, hogy a ketrecekben a megnövelt telepítési sűrűség negatív hatással volt a FCR értékekre.

\section{2. táblázat}

A szürke harcsa és ponty növekedési paraméterei (átlag_szórás)

\begin{tabular}{lllllll}
\hline $\begin{array}{l}\text { Keze- } \\
\text { lések }^{1}\end{array}$ & $\begin{array}{l}\text { Induló } \\
\text { test- }_{\text {tömeg }^{2}} \text { (g) }\end{array}$ & $\begin{array}{l}\text { Befejező } \\
\text { testtömeg } \\
\text { (g) }\end{array}$ & $\begin{array}{l}\text { Testtömeg } \\
\text { gyarapodás } \\
\text { (g) }\end{array}$ & $\begin{array}{l}\text { Relatív } \\
\text { növekedés }\end{array}$ & $\begin{array}{l}\text { SGR } \\
\text { (\%) }\end{array}$ & $\begin{array}{l}\text { FCR } \\
\text { (g/gap) }\end{array}$ \\
\hline $\mathrm{M}^{6}$ & $485,2 \pm 4,6$ & $1903,3 \pm 238,3$ & $1418,1 \pm 238,8$ & $292,3 \pm 49,6$ & $0,9 \pm 0,1$ & $1,4 \pm 0,4$ \\
$\mathrm{I}^{7} \mathrm{E}^{7}$ & $485,5 \pm 2,7$ & $2002,9 \pm 170,3$ & $1517,5 \pm 167,6$ & $312,6 \pm 32,8$ & $0,9 \pm 0,1$ & $1,4 \pm 0,4$ \\
Ponty $^{8}$ & $333,5 \pm 3,7$ & $2266,9 \pm 87,6$ & $1933,4 \pm 86,5$ & $579,7 \pm 25,1$ & - & - \\
\hline
\end{tabular}

Table 2. Production traits of European catfish and common carp (mean \pm SD). ${ }^{1}$ Treatments, ${ }^{2}$ Initial weight, ${ }^{3}$ Final weight, ${ }^{4}$ Weight gain, ${ }^{5}$ Body mass gain, ${ }^{6}$ Monoculture,, 7 Intensive-extensive, ${ }^{8}$ Common carp

A vizsgálat ideje alatt a tavak oldott oxigénszintje az I-E kezelésnél 7,16 $\pm 2,17 \mathrm{mg} / \mathrm{l}$, a M kezelésnél 7,73 $\pm 2,23 \mathrm{mg} / \mathrm{l}$ volt. A csoportok legmagasabb értékei 12,07 mg/l (I-E) és 13,18 mg/l (M) voltak. Az átlagos pH értékek

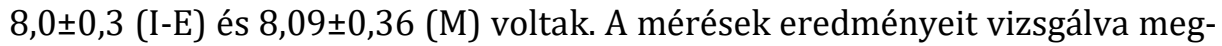
figyelhető volt, hogy a kezdési időpontot követően az adatok - bár az értékekben voltak ingadozások - folyamatosan csökkenő tendenciát mutattak. Ez egészen a 71. napig tartott. Ezt követően az adatokban növekedést figyeltem meg. Az átlagos vízhőmérséklet értékei (I-E: 20,5 $\pm 4,2{ }^{\circ} \mathrm{C}$; $\mathrm{M}: 20,3 \pm 4,2{ }^{\circ} \mathrm{C}$ ) között minimális eltérést tapasztaltam. A kísérlet kezdetén tapasztalt hideg időjárási körülmények következtében a víztér hőmérséklete az első két hétben $8{ }^{\circ} \mathrm{C}$-ot csökkent. Az adatok időbeni változását az 1. ábra szemlélteti. 


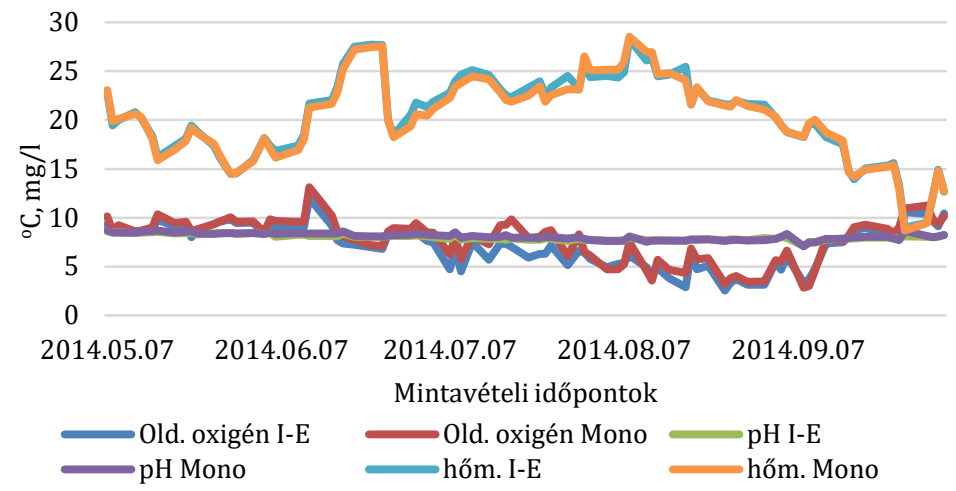

1. ábra

A vizsgált vízterek oldott oxigén, pH és hőmérséklet értékeinek az időbeli alakulása.

(Figure 1. Changes in the dissolved oxygen, $\mathrm{pH}$ and temperature values of the studied water bodies during the trial)

A vizsgálat során vett vízminták adatait a 3. táblázat tartalmazza. A különböző paraméterek adatainak a statisztikai vizsgálata során szignifikáns különbségeket tapasztaltam. A vizsgált nyolc paraméter közül négynél, a $\mathrm{NO}_{3}-\mathrm{N}$, a $\mathrm{PO}_{4}-\mathrm{P}$, a TSS és a Chl-a esetében a két kezelés adatai között jelentős eltérést tapasztaltunk. A TSS és a Chl-a adatok a két kezelésnél ellentétes tendenciát mutattak. A TSS az intenzív-extenzív kezelésnél több mint kétszeres volt a monokultúrás kezeléshez képest. Ez a jelentős különbség visszavezethető arra, hogy a ketreceken kívüli víztérbe a kísérlet elején kétnyaras pontyokat helyeztünk ki, melyek az aljzat folyamatos túrásával nagyobb mértékben keverték fel az üledéket, mint a szürke harcsa. A monokultúrás kezelésnél a minták Chl-a értékei az I-E kezelés értékeihez képest kétszeres eltérést mutattak. Ez a különbség szintén visszavezethető arra, hogy a kihelyezett pontyállomány az üledéket felkavarta, aminek következtében a víztér zavarosabb volt, ami miatt a víztestben csökkent a fény behatolásának a mértéke, ami csökkentette a fitoplankton nagyobb mértékű elszaporodását. A 28/2004. (XII.25.) KvVM rendelet 2. számú mellékletében a 3. számú területi kategóriánál megállapított határértékeket a vizsgálatunknál az összes lebegőanyag a monokultúrás kezelésnél 10,8 mg/l-rel, míg az I-E kezelésnél 88,7 mg/l-rel haladta meg, ami egyébként jellemző a tavi halgazdálkodásra. Gál és mtsai.(2016) szerint az intenzív tavak által kibocsátott lebegőanyag mennyisége csökkenthető, ha a lehalászás pontosan időzített, illetve időben elnyújtott. A határérték jelentős túllépésének 
az oka a tavakba nagy mennyiségben kihelyezett harcsa, illetve pontyállomány volt.

3. táblázat

A víz kémiai paraméterei (átlag士szórás)

\begin{tabular}{lllll}
\hline & $\begin{array}{l}\text { Ammónium-nitrogén } \\
(\mathrm{mg} / \mathrm{l})\end{array}$ & $\begin{array}{l}\text { Nitrát-nitrogén }^{2} \\
(\mathrm{mg} / \mathrm{l})\end{array}$ & $\begin{array}{l}\text { Nitrit-nitrogén }^{3} \\
(\mathrm{mg} / \mathrm{l})\end{array}$ & $\begin{array}{l}\text { Összes nitrogén }^{4} \\
(\mathrm{mg} / \mathrm{l})\end{array}$ \\
\hline $\mathrm{M}$ & $0,95 \pm 0,79$ & $0,36 \pm 0,43^{\mathrm{a}}$ & $0,14 \pm 0,19^{\mathrm{a}}$ & $4,56 \pm 3,11$ \\
$\mathrm{I}-\mathrm{E}$ & $0,78 \pm 0,54$ & $1,00 \pm 0,79^{\mathrm{b}}$ & $0,19 \pm 0,12^{\mathrm{b}}$ & $3,49 \pm 1,75$ \\
\hline & $\begin{array}{l}\text { Ortofoszfát-foszfor }^{5} \\
(\mathrm{mg} / \mathrm{l})\end{array}$ & $\begin{array}{l}\text { Összes foszfor }^{6} \\
(\mathrm{mg} / \mathrm{l})\end{array}$ & $\begin{array}{l}\text { Összes lebegőanyag }^{7} \\
(\mathrm{mg} / \mathrm{l})\end{array}$ & $\begin{array}{l}\text { Klorofill-a }^{8} \\
(\mathrm{mg} / \mathrm{l})\end{array}$ \\
\hline M & $0,18 \pm 0,12^{\mathrm{a}}$ & $0,54 \pm 0,42$ & $60,84 \pm 42,92^{\mathrm{a}}$ & $220,86 \pm 256,78$ \\
$\mathrm{I}-\mathrm{E}$ & $0,07 \pm 0,02^{\mathrm{b}}$ & $0,33 \pm 0,16$ & $138,69 \pm 87,74^{\mathrm{b}}$ & $110,07 \pm 120,37$ \\
\hline
\end{tabular}

Table 3. Chemical parameters of water (mean $\pm S D$ ). ${ }^{1}$ Ammonium-nitrogen, ${ }^{2}$ Nitrate-nitrogen, ${ }^{3}$ Nitrite-nitrogen, ${ }^{4}$ Total nitrogen, ${ }^{5}$ Orthophosphate, ${ }^{6}$ Total phosphorus, ${ }^{7}$ Total suspended solids, ${ }^{8}$ Chlorofill-a

Bucur és mtsai. (2016) intenzív-extenzív tavi rendszerben végzett kísérletében a vízkémiai paraméterek hasonlóak voltak az általunk tapasztaltakhoz. Intenzív-extenzív tavi rendszerben, nílusi tilápiával és ponttyal végzett kísérletükben Diab és mtsai. (1992) a szervetlen nitrogén mutatók esetében hasonló eredményekről számoltak be. Yi és Lin (2001) kísérletükben a tavakban elhelyezett ketrecek számának növelésének a hatását vizsgálták. Azt tapasztalták, hogy az összes lebegőanyag mennyisége folyamatosan emelkedett a vizsgálat végéig, köszönhetően a halak üledékkavaró hatásának. Yi és mtsai. (2003) integrált rendszerű vizsgálatukban az összes $\mathrm{N}$ és összes $\mathrm{P}$ mennyiségében szignifikáns különbséget találtak a kezelések között. Osztott tavi rendszerben végzett vizsgálatukban Jescovitch és mtsai. (2017) szignifikáns különbséget találtak a kontroll és a kezelt csoportok (plusz levegőztetés) között a TAN, az összes N és az összes P mutatókban. Kwei Lin és Diana (1995) hibrid harcsával (Clarias macrocephalus $x$ C. gariepinus) és nílusi tilápiával végzett ketreces tavi kísérletükben a TAN értékek a vizsgálat második felére jelentősen megemelkedtek minden csoportnál. Yi és mtsai. (1996) tavi ketreces kísérletükben az általuk vizsgált vízkémiai mutatókban nem találtak különbségeket a kezelések között.

A 2., 3. és 4. ábra az összes nitrogén, az összes szervetlen nitrogén és az összes szerves nitrogén időbeli változását szemlélteti. Amint az ábrákon látható, az intenzív-extenzív kezelésnél a nitrogén-tartalmú paraméterek változása közel egyenletes volt. Ezzel ellentétben a monokultúrás kezelésnél az öszszes nitrogén és az összes szerves nitrogén értékei a kísérlet második felében nagymértékben eltértek az intenzív-extenzív kezelés értékeitől. A 6. ábrán látható, hogy a monokultúrás kezelésnél a szerves nitrogén mennyisége az 5. 
mintavételtől kezdve nagymértékű növekedésnek indult. Ez összefüggésben áll a klorofill-a időbeli változásával, mely hasonló képet mutatott. Az ábrákon látható, hogy mind a három paraméter a 7. mintavétel időpontjában érte el a maximumát. Ez a monokultúrás kezelésnél 8,49 mg/l, 2,71 mg/l, 5,78 mg/l, míg az intenzív-extenzív kezelésnél 5,02 mg/l, 3,13 mg/l, 1,89 mg/l. A kombinált népesítés esetén a víztest alacsonyabb összes $\mathrm{N}$ tartalma, az extenzív komponens szűrő hatásával magyarázható, amikor az extenzív egységben jelentős mennyiségü szerves nitrogén akkumulálódik a ponty járulékos tömeggyarapodásában. Mindez azt is eredményezi, hogy a kombinált rendszerben a haltermelés tápanyag-transzformációs hatásfoka a járulékos extenzív halhozammal együtt meghaladja a monokultúrás tavakét.

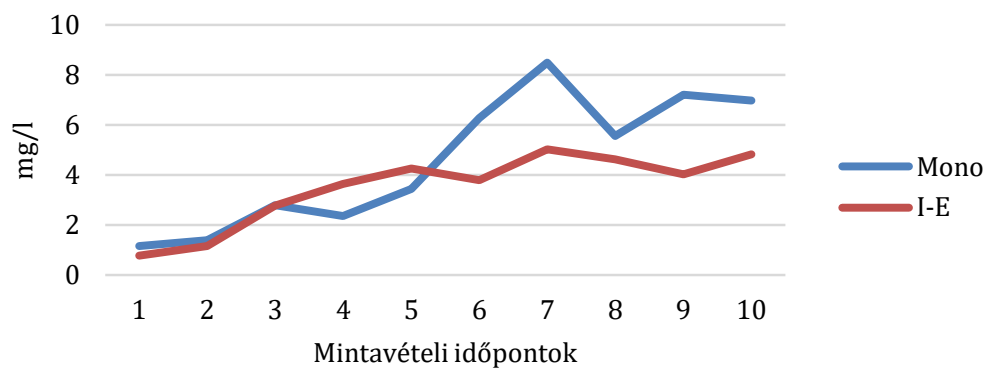

\section{2. ábra}

A vizsgált vízterek összes nitrogén értékeinek időbeli alakulása. (Figure 2. Changes in the total nitrogen values of the studied water bodies during the trial)

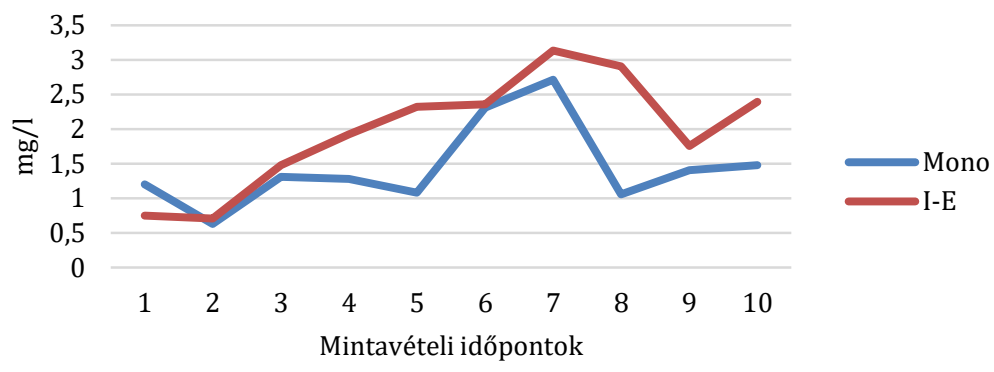

\section{3. ábra}

A vizsgált vízterek összes szervetlen nitrogén értékeinek időbeli alakulása. (Figure 3. Changes in the total inorganic nitrogen values of the studied water bodies during the trial) 


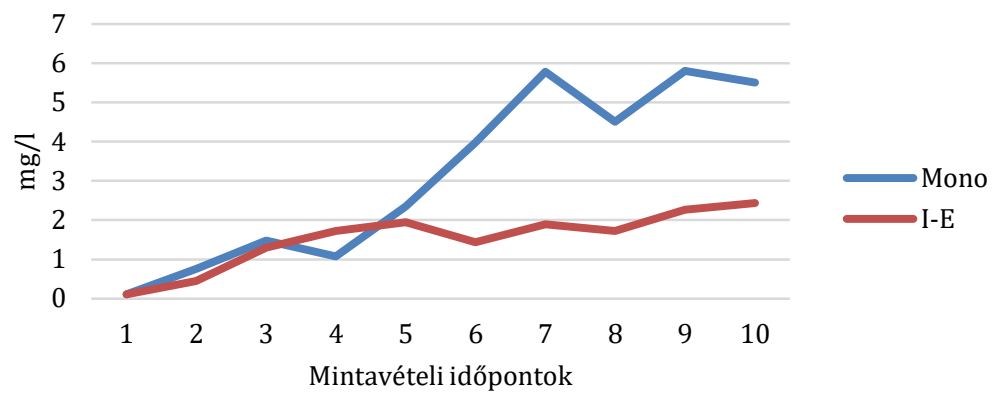

\section{4. ábra}

A vizsgált vízterek összes szerves nitrogén értékeinek időbeli alakulása. (Figure 4. Changes in the total organic nitrogen values of the studied water bodies during the trial)

Az 5. ábra az ortofoszfát-foszfor időbeli változását mutatja be a vizsgálat ideje alatt. Hasonlóan a nitrogén-tartalmú paraméterekhez a két kezelés értékei között a kísérlet második felére nagymértékű különbség alakult ki. A maximális értékeket szintén a 7. mintavétel időpontjában kaptam. Ez a monokultúrás kezelésnél $0,33 \mathrm{mg} / \mathrm{l}$, az intenzív-extenzív kezelésnél $0,084 \mathrm{mg} / \mathrm{l}$ volt. Ez a különbség ugyancsak a kombinált rendszer extenzív tavának tápanyag akkumuláló képességével magyarázható. Az extenzív rész kiegészítő ponty népesítésével jelentősen megnőtt a szerves anyag - beleértve a szerves formált foszfort is - eltávolítás mértéke.

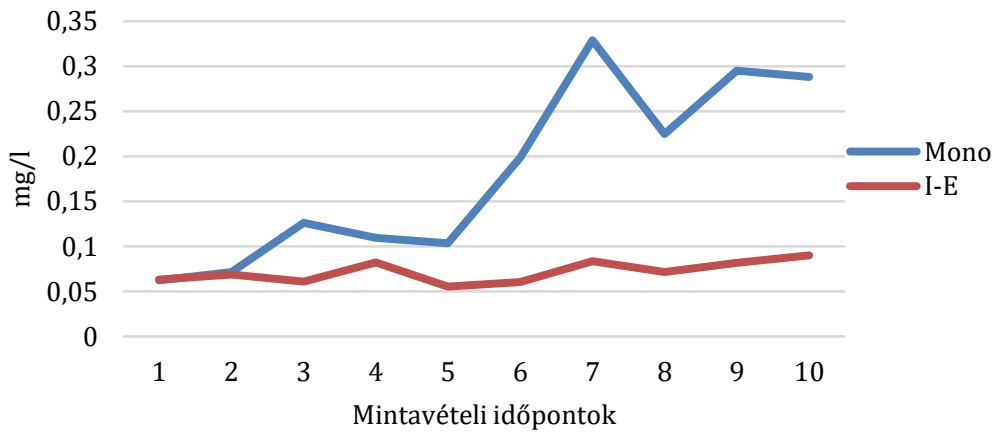

\section{5. ábra}

A vizsgált vízterek ortofoszfát-foszfor értékeinek időbeli alakulása. (Figure 5. Changes in the ortophosphate-phosphorus values of the studied water bodies during the trial) 
A vizsgálat kezdetén és a befejezést követően a tavakból vett üledékminták elemzésének az adatait a 4. táblázat tartalmazza. A táblázat adataiból látható, hogy mind a két kezelésnél a minták szárazanyag-tartalma a kísérlet végére csökkent. A csökkenés mértéke a kezeléseknél 30 \% (M) és $15 \%$ (I-E) volt. A további két vizsgált paraméternél (KN és a P) - hasonlóan a vízminták TSS és Chl-a adataihoz - a kapott értékek a két kezelés között ellentétes irányban változtak. A KN értékek a monokultúrás kezelésnél 78 \%-kal emelkedtek, míg ezzel szemben az intenzív-extenzív kezelésnél 26 \%-kal csökkentek. Hasonló tendenciát figyeltem meg a foszfor esetében is. A monokultúrás csoportok tavaiból vett mintákban a foszfor-tartalom 57 \%-kal növekedett a kísérlet végére, míg az intenzív-extenzív kezelésnél a mintákban a foszfor-tartalom 35 \%kal csökkent. Mindez arra enged következtetni, hogy a kombinált rendszerben a haltermelés tápanyag transzformációja meghaladta a monokultúráét. Az extenzív tó jelentős mennyiségű szerves N és P vegyületet vont ki és akkumulált a kiegészítő pontyhozamban. Hasonló jelenség volt megfigyelhető a víztest $\mathrm{N}$ és $\mathrm{P}$ tartalmában is. Ezzel szemben hibrid harcsával (Clarias macrocephalus $\mathrm{X}$ C. gariepinus) és nílusi tilápiával végzett vizsgálatukban Yi és mtsai. (2003) az összes $\mathrm{N}$ és összes $\mathrm{P}$ mennyiségében minimális növekedést figyeltek meg a vizsgálat ideje alatt a kezelések között.

\section{4. táblázat}

Az üledék szárazanyag, Kjeldahl-N, valamint foszfortartalma a kísérlet kezdetén és végén

\begin{tabular}{lll|ll}
\hline & & $\begin{array}{l}\text { Szárazanyag1 } \\
\text { (m/m \%) }\end{array}$ & $\begin{array}{l}\text { Kjeldahl-N2 } \\
\text { (mg/kg szá.a.) }\end{array}$ & $\begin{array}{l}\text { Foszfor }^{3} \\
\text { (mg/kg szá.a.) }\end{array}$ \\
\hline \multirow{2}{*}{ M } & Induló $^{4}$ & $61,5 \pm 11,3$ & $1630,8 \pm 1515,9$ & $1133,6 \pm 751,8$ \\
& Befejező $^{5}$ & $43,3 \pm 10,6$ & $2901,5 \pm 1661,8$ & $1778,8 \pm 1654,1$ \\
\multirow{2}{*}{ I-E } & Induló $^{2}$ & $69,2 \pm 6,4$ & $1622,5 \pm 1826,5$ & $2001,5 \pm 2023,4$ \\
& Befejező & $60,4 \pm 7,7$ & $1200,8 \pm 859,0$ & $1299,9 \pm 1318,4$ \\
\hline
\end{tabular}

Table 4. Dry matter, Kjeldahl-nitrogen and phosphorus content of sediment at initial and final stage of the trial. ${ }^{1}$ Dry matter, ${ }^{2}$ Kjeldahl-nitrogen, ${ }^{3}$ Phosphorus, ${ }^{4}$ Initial, ${ }^{5}$ Final

\section{KÖVETKEZTETÉSEK}

Az eltérő tartástechnológiában (M; I-E) nevelt állományok növekedési paramétereiben nem találtunk szignifikáns különbséget. A két csoport FCR és SGR értékei azonosak voltak. Mind a takarmányértékesítés, mind pedig a speciális növekedési sebesség értékei feltehetően javíthatóak a monokultúrás csoportnál a helyes etetési gyakoriság, valamint az etetés hosszának a megfelelő megválasztásával. Az I-E csoportnál a ketrecekben a telepítési sűrűség módosításával mérsékelhető a halak általi pazarlás. Az I-E kezelésnél a ketrecen kívüli víztérbe kihelyezett pontyállomány esetén jelentős tömeggyarapodás érhető 
el a harcsák által el nem fogyasztott táp, valamint a harcsa ürülékét hasznosító élőlények fogyasztása kapcsán. A tenyészidőszak végén a ponty, mint "melléktermék" plusz bevételi forrást jelenthet a gazdálkodók számára. A tavak kis mérete, a kihelyezett állományok nagy sűrűsége (szürke harcsa $2857 \mathrm{~kg} / \mathrm{ha}$; ponty $714 \mathrm{~kg} / \mathrm{ha}$ ), illetve a lapátkerekes levegőztetés hozzájárult a vízminták magas lebegőanyag-koncentrációjához.

Köszönetnyílvánítás: A vizsgálatokat a Gazdaságfejlesztési Operatív Program által támogatott „Minőségváltás a hagyományos halastavi struktúrákon történő haltenyésztésben; újszerű, komplex tenyésztési, takarmányozási és környezetkezelési technológia kifejlesztése" című projekt keretében végeztük (GOP-1.1.1-11-2011-0028).

\section{IRODALOMJEGYZÉK}

Avnimelech, Y., Weber, B., Hepher, b., Milstein, A., Zorn, M. (1986). Studies in circulated fish ponds: organic matter recycling and nitrogen transformation. Aquaculture and Fisheries Management, 17(4), 231-242. DOI: 10.1111/j.1365-2109.1986.tb00109.x

Colt, J., Armstrong, D. (1979). Nitrogen toxicity to fish, crustaceans and molluscs. Department of Civil Engineering, University of California, Davis, CA, 30 pp.

Diab, S., Kochba, M., Mires, D., Avnimelech, Y. (1992). Combined intensive-extensive (CIE) pond system A: inorganic nitrogen transformations. Aquaculture, 101(1-2), 33-39. DOI: 10.1016/0044$\underline{8486(92) 90230-i}$

FAO (2018). The State of World Fisheries and Aquaculture 2018 - Meeting the sustainable development goals. Rome.

Gál, D., Pekár, F., Kerepeczki, É. (2016). A survey on the environmental impact of pond aquaculture in Hungary. Aquaculture International, 24(6), 1543-1554. DOI: 10.1007/s10499-016-0034-9

IBM Corp. Released (2013). IBM SPSS Statistics for Windows, Version 22.0. Armonk, NY: IBM Corp.

Jescovitch, L.N., Boyd, C.E., Withis, G.N. (2017). Effects of mechanical aeration in the waste-treatment cells of split-pond aquaculture systems on water quality. Aquaculture, 480, 32-41. DOI: 10.1016/j.aquaculture.2017.08.001

Kibria, A.S.M., Haque, M.M. (2018). Potentials of integrated multi-trophic aquaculture (IMTA) in freshwater ponds in Bangladesh. Aquaculture Reports, 11, 8-16. DOI: 10.1016/j.aqrep.2018.05.004

Kwei Lin, C., Diana, J.S. (1995). Co-culture of catfish (Clarias macrocqbhalus x C. gariepinus) and tilapia (Oreochromis niloticus) in ponds. Aquatic Living Resources, 8(4), 449-454. DOI: $\underline{10.1051 / a l r: 1995054}$

Ludwig, G.M. (1996). Comparison of channel catfish, Ictalurus punctatus, and fathead minnow, Pimephales promelas, production and water quality among a polyculture and two monoculture systems. Aquaculture, 144(1-3), 177-187. DOI: $\underline{10.1016 / \text { S0044-8486(96)01300-2 }}$

Palachek, R.M., Tomaso, J.R. (1984). Toxicity of nitrite to channel catfish (Ictalurus punctatus), tilapia (Tilapia aurea) and largemouth bass (Micropterus salmoides): evidence for nitrite exclusion mechanism. Canadian Journal of Fisheries and Aquatic Sciences, 41(12), 1739-1744. DOI: $\underline{10.1139 / f 84-214}$

Sun, W., Boyd, C.E. (2013). Phosphorus and nitrogen budgets for inland, saline water shrimp ponds in Alabama. Fisheries and Aquaculture Journal, 4(1), 1-5. DOI: 10.4172/2150-3508.1000080 
Yi, Y., Kwei Lin, C. (2001). Effects of biomass of caged Nile tilapia (Oreochromis niloticus) and aeration on the growth and yields in an integrated cage-cum-pond system. Aquaculture, 195(3-4), 253-267. DOI: $10.1016 / S 0044-8486(00) 00558-5$

Yi, Y., Kwei Lin, C., Diana, J.S. (1996). Influence of Nile tilapia (Oreochromis niloticus) stocking density in cages on their growth and yield in cages and in ponds containing the cages. Aquaculture, 146(3-4), 205-215. DOI: $\underline{10.1016 / S 0044-8486(96) 01377-4}$

Yi, Y., Kwei Lin, C., Diana, J.S. (2003). Hybrid catfish (Clarias macrocephalus x C. gariepinus) and Nile tilapia (Oreochromis niloticus) culture in an integrated pen-cum-pond system: growth performance and nutrient budgets. Aquaculture, 217(1-4), 395-408. DOI: 10.1016/S0044-8486(02)00540-9

Zhang, K., Yu, D., Li, Z., Xie, J. (2020). Influence of eco-substrate addition on organic carbon, nitrogen and phosphorus budgets of intensive aquaculture ponds of the Pearl River, China. Aquaculture, 520, 15 April 2020, 734868. DOI: 10.1016/j.aquaculture.2019.734868

(C) Copyright 2020 by the authors. This is an open access article under the terms

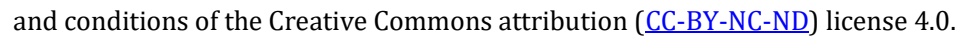

